\title{
ЗАСТОСУВАННЯ ОСНОВНИХ ФОРМ І МЕТОДІВ У ВИВЧЕННІ КУРСУ «ФІНАНСОВА ГРАМОТНІСТЬ» У ГІМНАЗІЇ
}

\author{
Наталія Барадія \\ кандидат педагогічних наук \\ науковий співробітник відділу \\ навчання географії та економіки \\ Інституту педагогіки НАПН України \\ jolly2008@ukr.net
}

\begin{abstract}
Анотація. Стаття є дослідженням важливості формування фінансової грамотності в сучасної молоді. Здійснено акцент на тому, що фінансова освіта допомагає здобувачам освіти зрозуміти ключові фінансові поняття та використовувати їх для прийняття рішень у фінансових питаннях, для вибору відповідних фінансових інструментів, планування бюджету, нагромадження коштів на майбутні цілі тощо. Виявлено особливості ефективного викладання курсу «Фінансова грамотність» у гімназії. Розглянуто різноманітні підходи до процесу викладання цього курсу та охарактеризовано найбільш ефективні 3 них.
\end{abstract}

Ключові слова: економічна соціалізація; фактори економічної соціалізації; економічна культура; фінансова грамотність; фінансова освіта.

Постановка проблеми в загальному вигляді. Зміст громадянської освіти передбачає інтеграцію соціально-гуманітарних знань із різних навчальних предметів та орієнтацію на розв'язання практичних проблем. Формування цілісного світогляду в здобувачів освіти та набуття ними інтегративних громадянознавчих знань включає економічний напрям, пов'язаний із формуванням знань про економіку в повсякденному житті родини, місцевої громади, українського суспільства та розвиток ключових економічних компетентностей громадянина [5].

Розвиток економічної та фінансової грамотності, дотримання правових норм в економічному житті, участь у творенні громадянського суспільства. Зазначений курс розрахований на всю освітню вертикаль, починаючи 3 початкової ланки, має повне навчально-методичне забезпечення і передбачає реалізацію наскрізної змістової лінії «Підприємливість та фінансова грамотність». Саме ця лінія відбиває одну з провідних соціально й особистісно значущих ідей, що послідовно розкривається в навчанні та вихованні здобувачів освіти, є засобом інтеграції навчального змісту, корелюється 3 ключовими компетентностями, опанування яких забезпечує формування ціннісних i світоглядних орієнтацій здобувача освіти, що визначають його поведінку в життєвих ситуаціях. У старшому шкільному віці якісно змінюється структура навчальної мотивації особистості: навчальна діяльність стає для неї засобом реалізації життєвих планів майбутнього.

Аналіз останніх досліджень і публікацій Основу загальнонаукових, психолого-педагогічних ідей соціалізації особистості становлять ідеї 
Застосування основних форм і методів у вивченні курсу «Фінансова грамотність» у гімназії

Л. Виготського (теорія соціального середовища як визначального чинника виховного процесу), С. Рубінштейна (теорія діяльності як позиція стосовно суспільства), Т. Кравченко (виховання як важливий фактор соціалізації), Н. Мойсеюк (становлення особистості в процесі соціалізації) та ін.

Зазначимо, що певні аспекти формування фінансової грамотності населення як одного із пріоритетів державної політики на сучасному етапі розглядали Л. Захаркіна, Л. Зюман, Т. Кізима, В. Корнівська, А. Кузнєцова, Г. Кучерова, І. Ломачинська, Д. Радзішевська, Т. Смовженко та інші. Проблеми впровадження фінансової освіти в закладах освіти України вивчали I. Вітенко, О. Губенко, М. Короденко, О. Костюкова, Т. Смовженко та інші [3].

Формулювання цілей статті. Метою статті $\epsilon$ визначення особливостей застосування основних форм і методів у вивченні курсу «Фінансова грамотність» у гімназії.

Методи дослідження в роботі використані такі: пошуковий: за наявною методичною та науковою літературою із аналізом знайденого матеріалу; 3'ясування причинно-наслідкових зв'язків; систематизація; абстрагування та конкретизація; аналіз документації та результатів діяльності дослідників із проблеми проведеного дослідження.

Результати дослідження. На сьогодні в суспільстві існують чинники, які змушують впроваджувати роботу щодо формування фінансової грамотності громадянина якнайраніше: можливість охоплення навчанням усіх верств населення, незалежно від їхніх матеріальних статків, чим закладається підгрунтя фінансової компетенції цілого покоління; стрімкий ріст кількості здобувачів освіти, які починають приймати самостійні фінансові рішення в більш ранньому віці; саме в ранньому віці закладаються засади загальнолюдської культури й стимули до навчання впродовж усього життя. I завдання педагогів полягає в тому, щоб давати не лише готові економічні знання, а й створювати умови для формування в майбутнього покоління основ фінансової безпеки [2].

Усі програми та навчально-методичне забезпечення з курсу «Фінансова грамотність» можна використовувати як для варіативної складової навчальних планів, так і під час проведення факультативних занять і гурткової роботи. Завдання предметів і курсів економічного спрямування забезпечать створення умов для соціального і професійного самовизначення, отримання соціального досвіду, що сприяє активній життєвій і громадянській позиції випускника гімназії. Під час роботи за зазначеними вище навчальними програмами вчитель має право коригувати кількість годин залежно від можливостей навчального закладу.

Пропоновані курси за вибором можуть викладатися за рахунок варіативного компонента змісту освіти для забезпечення пізнавальних і освітніх потреб здобувачів освіти та використовуватись незалежно від обраного профілю навчання й стати актуальними для здобувачів освіти в гімназії. Тим самим забезпечується гнучка система профільного навчання, яка надає здобувачам освіти можливість обрати індивідуальну освітню програму [3]. 
Застосування основних форм і методів у вивченні курсу «Фінансова грамотність» у гімназії

Курс «Фінансова грамотність» має вирішувати такі завдання: поглиблення знань із макроекономіки, усвідомлення сутності та ролі фінансів і фінансових відносин у політичному, економічному та соціальному житті; з'ясування значення фінансової освіти як одного з чинників економічної стабільності; проектування методичної системи впровадження фінансової грамотності в гімназії.

Навчальний матеріал надається під час проведення лекцій різних типів, виконання практичних робіт у групах, участі в проведенні семінарських занять, круглих столів, тестуванні та інших формах роботи.

Навчальна стратегія курсу може реалізовуватися також через дистанційну (або очно-дистанційну) форму навчання шляхом проведення Інтернетконсультацій та виконання індивідуальних практичних завдань; самостійного вивчення слухачами навчального матеріалу, рекомендованого викладачами спецкурсу.

Для презентації конспектів уроків рекомендуємо використати панорамний урок - своєрідний панорамний огляд системи уроків курсу, у якому беруть участь декілька педагогів, які взаємно доповнюють одне одного та визначають найбільш ефективні методи та прийоми роботи із здобувачами освіти.

Курс «Фінансова грамотність» слід спрямувати на виконання таких основних завдань: надання знань 3 основ економічної теорії та набуття економічних компетенцій у сфері фінансових послуг; формування економічної культури вчителів та мотивації до подальшої економічної самоосвіти; удосконалення вмінь самоосвітньої діяльності [3].

Курс «Фінансова грамотність» має вирішувати такі завдання: поглиблення знань із макроекономіки, усвідомлення сутності та ролі фінансів і фінансових відносин у політичному, економічному та соціальному житті; з'ясування значення фінансової освіти як одного з чинників економічної стабільності; проектування методичної системи впровадження фінансової грамотності.

Завдання для самостійної роботи слід оріснтувати на збір та опрацювання матеріалів про розвиток системи фінансової освіти; створення власних розробок конспектів уроків із курсу «Фінансова грамотність»; розробку презентацій власних проектів; розв'язування тестових завдань тощо. Усі ці матеріали об'єднуються в методичний порадник учителя предмета «Фінансова грамотність» [1].

Формування фінансових компетенцій клієнта банку продовжується в 5-му класі при вивченні теми «Запозичення та заощадження родини», у 6-му класі здобувачі освіти знайомляться 3 зародженням банківської системи, у курсі «Прикладні фінанси» (8 клас) вивчають розділ «Я - клієнт банку», у 9-му вчаться управляти банківським рахунком. Змістова лінія «Я - підприємець» доповнюється темою «Сімейне підприємництво» (5 клас), шляхи досягнення фінансового успіху розглядаються у 8-му класі [4]. 
Застосування основних форм і методів у вивченні курсу «Фінансова грамотність» у гімназії

Ступенева шкільна фінансова освіта сприятиме формуванню економічних (соціальних) ролей, а отже, економічній соціалізації здобувачів освіти. Важливо, що гімназія, залишаючись головною ланкою освітнього процесу, перестає бути єдиним джерелом навчальної інформації. В освітній простір активно входять професійні учасники фінансового ринку, тобто мова йде про створення системи партнерства в області фінансової освіти для забезпечення практичної складової навчання.

В економічній соціалізації здобувачів освіти особливу роль має позакласна робота з курсу «Фінансова грамотність». Успіх ії залежить від реалізації чіткої системи взаємопов'язаних заходів, які підготовлені з урахуванням інтересів $\mathrm{i}$ вікових особливостей здобувачів освіти. Соціалізуюча дія цих заходів значно посилюється, якщо всі учасники активно взаємодіють: створюють проекти, аналізують результати, дискутують, діляться враженнями тощо [2].

Роль сім’ї в процесі економічної соціалізації здобувачів освіти $\epsilon$ незаперечною, адже економічна свідомість, як правило, закладається в сім'ї. Проте однією з проблем формування економічної культури молоді є низька економічна культура дорослих, тому одним із завдань гімназії $є$ організація економічної просвіти батьків. Саме на це спрямований курс для батьків «Відкриті родинні студії. Фінансова мудрість родинної педагогіки».

Важливу роль у підвищені фахової обізнаності відіграють хмарні технології. Основні компанії: Google, Microsoft, IBM намагаються вдосконалити хмарні технології для їхнього впровадження в освітній процес. Сучасні вебсервіси в хмарі $є$ важливою системою, завдяки якій створюються певні навчальні середовища для підвищення кваліфікації вчителів i розвитку їхнього професіоналізму та можливість залучити до освітнього процесу здобувачів освіти та їхніх батьків через використання досягнень Інтернет-технологій, електронних додатків для освіти.

Важливою складовою навчання здобувача освіти основам фінансової грамотності є участь у проектній та дослідницькій роботі. Саме ця складова навчання дозволяє забезпечити діяльнісний підхід у навчанні, формування базових економічних і фінансових компетенцій, які необхідні кожній молодій людині та мають сприяти підвищенню їі конкурентоздатності на ринку праці [6].

Щороку проектом готується звіт про результати проведення підсумкової контрольної діагностики рівня фінансової грамотності здобувачів освіти закладів загальної середньої освіти та вищих навчальних закладів I-II рівнів акредитації, залучених до дослідно-експериментальної роботи в країні. За результатами вступної та заключної перевірки на першому етапі експерименту рівень знань зріс на $20 \%$.

Метод конкретних ситуацій - метод активного проблемно-ситуаційного аналізу, заснований на навчанні шляхом вирішення конкретних проблем; метод навчання, при якому здобувачі освіти i викладачі беруть участь у безпосередньому обговоренні ділових ситуацій. Ці ситуації (кейси) складаються з урахуванням досвіду реальних людей, які працюють у сфері підприємництва, 
Застосування основних форм і методів у вивченні курсу «Фінансова грамотність» у гімназії

вивчаються, аналізуються i обговорюються здобувачами освіти. Ці кейси складають основу для бесід у класі під керівництвом викладача [7].

Безпосередня мета методу case-study - спільними зусиллями групи i здобувачами освіти проаналізувати ситуацію, яка має місце в реальному житті, $\mathrm{i}$ розробити практичне їі вирішення; закінчення процесу - оцінка і вибір кращого iз запропонованих алгоритмів вирішення проблеми.

Для ефективного використання кейс-методу необхідно створювати спеціальні умови, до складу яких входять: забезпечення достатньо високої складності пізнавальних проблем, які потрібно вирішувати здобувачам освіти; створення викладачем логічного ряду запитань щодо пізнавальної проблеми, які спонукають здобувачів освіти до пошуку істини; створення в аудиторії атмосфери психологічного комфорту, яка має сприяти вільному висловлюванню їх думки, не боячись помилки; відведення спеціального часу на осмислення способів вирішення проблеми; організація спеціальної підготовки викладачів до запровадження методики.

До переваг методу case-study можна віднести: використання принципів проблемного навчання; отримання навичок роботи в команді; набуття досвіду презентації результатів роботи; уміння формулювати питання, аргументувати відповідь. Його реалізація пов'язана зі здійсненням моделювання, системного аналізу, проблемного й ігрового методів, уявного експерименту, а також методів опису і класифікації, кожен із яких виконує в кейс-методі свою роль [5].

Використання методу case-study в навчанні здобувачів освіти фінансової математики дозволяє підвищити пізнавальний інтерес до математики як навчальної дисципліни, що дозволяє вирішувати життєві проблеми; сприяє розвитку дослідницьких, комунікативних і творчих навичок як необхідних рис підприємця; підвищує фінансову грамотність майбутніх громадян України.

Зазначимо, що впровадження та викладання курсу вимагає застосування певних форм і методів роботи з учителями. Залучення вчителів до участі в семінарах, творчих групах, узагальнення передового педагогічного досвіду сприяє популяризації фінансових знань і формуванню економічної свідомості самого вчителя, зростанню вмотивованості вчителя до поширення фінансової освіти.

Необхідною умовою економічної соціалізації, яка забезпечує безболісне входження здобувачів освіти в економічний простір, є їхня підготовка до виконання економічних ролей, а отже, й сформованість у них економічної культури. Відповідно, шкільна фінансова освіта та виховання сприяють формуванню економічної свідомості та економічного мислення здобувачів освіти, тобто економічної культури, яка обумовлює їхню економічну поведінку у фінансовій сфері через виконання певних економічних (соціальних) ролей.

Фінансова поведінка - це поведінка щодо прийняття фінансових рішень, тобто це вибір того чи того варіанту розв'язання фінансової проблеми. Здійснюючи вибір, здобувач освіти виступає в певній економічній (соціальній) 
Застосування основних форм і методів у вивченні курсу «Фінансова грамотність» у гімназії

ролі, тобто демонструє здатність реалізувати отримані економічні (фінансові) знання та виявляти економічне мислення, тобто фінансову компетенцію [1].

Фінансове виховання здійснюється впродовж тривалого періоду на основі принципу «від простого до складного», у процесі багаторазового повторення i закріплення, спрямованого на практичне застосування знань і навичок. Щоб здійснювати позитивний i довгостроковий вплив на учасників, програми фінансової грамотності повинні бути засновані на сучасних і зрозумілих прикладах із реальної практики з урахуванням тенденцій і змін, що відбуваються у фінансовій сфері, підготовлені і представлені за участю професійного фінансового співтовариства. Тому формувати виважене ставлення до власних фінансів необхідно починати якомога раніше.

Для поглиблення i розширення змісту профільних предметів або забезпечення профільної прикладної і початкової професійної спеціалізації навчання в гімназії пропонуються курси за вибором, які враховують інтереси, здібності та життєві плани здобувачів освіти, з одного боку, і відповідають профілю, з іншого. До варіативної частини віднесено такі економічні курси: «Основи підприємницької діяльності», «Власна справа», «Основи менеджменту», «Основи інтелектуальної власності», «Основи споживчих знань», «Цікава економіка», «Глобалізація», «Я - клієнт банку», «Клієнт банку», «Основи казначейської справи». Особливу роль у формуванні фінансової компетенції відіграє курс за вибором «Фінансова грамотність», підготовлений Університетом банківської справи Національного Банку України, мета якого ознайомити здобувачів освіти 3 сучасними фінансовими продуктами та послугами, розвивати в них навички використання таких продуктів, а також уміння планувати власне фінансове майбутне [3].

Отже, упровадження курсу «Фінансова грамотність» сприятиме розвитку як у здобувачів освіти, так і в учителів тих навичок і вмінь, які дозволять молоді приймати обгрунтовані й зважені фінансові рішення та готуватися до дорослого життя. Адже фінансова освіченість громадян - це найперший поштовх до кращого економічного майбутнього держави. Ураховуючи перспективи розробки програм курсу «Фінансова грамотність» для здобувачів освіти, актуальною $є$ проблема підготовки вчителів цих категорій до впровадження фінансової освіти в закладах загальної середньої освіти.

Наукова новизна результатів дослідження полягає в наявності оригінального дослідницького матеріалу за напрямом проведеного дослідження. Виявлені особливості ефективного викладання курсу «Фінансова грамотність» у гімназії. Відповідно до вищезазначеного матеріалу доцільним уважаємо здійснити акцент при плануванні роботи на ресурсному забезпеченні цієї діяльності (кабінет економіки або кабінет фінансової освіти, інформативні стенди економічного та фінансового змісту, шкільна економічна газета тощо); важливим $\epsilon$ планування та реалізація системи заходів позакласної роботи 3 фінансової освіти та виховання. 
Застосування основних форм і методів у вивченні курсу «Фінансова грамотність» у гімназії

Висновки з дослідження і перспективи подальших розвідок у цьому напрямі. Ураховуючи актуальність формування фінансової компетентності здобувачів освіти, упровадження курсу «Фінансова грамотність» та його навчально-методичне забезпечення дозволяє починати їхнє формування в початковій ланці, продовжувати в основній та завершувати в старшій, забезпечуючи наступність у їхньому формуванні.

Ситуація ускладнюється тим, що на процес економічної соціалізації, крім гімназії, впливають інші численні соціальні чинники: сім'я, позашкільні заклади, громадські організації, засоби масової інформації тощо. Учителю важливо визначити і пояснити здобувачам освіти ті проблемні ситуації, які пов'язані іноді 3 подвійними стандартами, що виникають у сучасному житті.

Отже, фінансова освіта є дієвим чинником економічної соціалізації, і цей процес здійснюється впродовж життєдіяльності здобувачів освіти та вчителів. За результатами викладання курсу за вибором «Фінансова грамотність» доцільно здійснити моніторинг оцінки рівня фінансової грамотності здобувачів освіти та визначити актуальні напрями подальшої роботи щодо впровадження фінансової освіти в гімназіях.

\title{
СПИСОК ВИКОРИСТАНИХ ДЖЕРЕЛ
}

1. Бібік, Н.М., Вашуленко, Л.С. і Локшината, О.І. (2004). Компетентнісний підхід: рефлексивний аналіз застосування. Компетентнісний підхід у сучасній освіті. Світовий досвід та українські перспективи: б-ка 3 освітньої політики. О.В. Овчарук (Ред.), с. 47-52. Київ, Україна.

2. Ковтун, Г.І. і Мартиненко, О.В. (2013). До питання формування економічної компетентності. Педагогічні науки: теорія, історія, інноваційні технології, 4, 135-144.

3. Литвинова, С.Г. (Ред.). (2011). Досвід учителів України з використання хмарних сервісів у системі загальної середньої освіти. Київ: ТОВ ЦП «КОМПРИНТ».

4. Овсюк, Н. (2011). Формування економічної компетентності у процесі вивчення географії Компетентнісний підхід до професійного розвитку вчителя та основ економіки. Географія та основи економіки в школі, 1, 37-41.

5. Пометун, O.I. (2005). Компетентнісний підхід - найважливіший орієнтир розвитку сучасної освіти. Рідна школа, 1, 65-69.

6. Химинець, В. (б.д.). Компетентнісний підхід до професійного розвитку вчителя. Взято з http: // zakinppo. org. ua / 2010-01-18-13-44-15 / 233-2010-08-25-07-10-49/.

7. Часнікова, О.В. Компетентнісний підхід в освіті як основа ї̈ реформування. Взято 3 https: // www. narodnaosvita. kiev. ua / ?page_id=2607.

\section{ПРИМЕНЕНИЕ ОСНОВНЫХ ФОРМ И МЕТОДОВ В ИЗУЧЕНИИ КУРСА «ФИНАНСОВАЯ ГРАМОТНОСТЬ» В ГИМНАЗИИ}

\author{
Наталья Барадия \\ кандидат педагогических наук \\ научный сотрудник отдела \\ изучение географии и экономики \\ Институт педагогики НАПН Украины
}


Застосування основних форм і методів у вивченні курсу «Фінансова грамотність» у гімназії

\title{
jolly2008@ukr.net
}

Аннотация. Статья является исследованием важности формирования финансовой грамотности у современной молодежи. Осуществлен акцент на финансовое образование помогает соискателям образования понять ключевые финансовые понятия и использовать их для принятия решений в финансовых вопросах, для выбора соответствующих финансовых инструментов, планирование бюджета, накопление средств на будущие цели и тому подобное. Выявлены особенности эффективного преподавания курса «Финансовая грамотность» в гимназии. Рассмотрены различные подходы к процессу преподавания данного курса и охарактеризованы наиболее эффективные из них.

Ключевые слова: экономическая социализация, факторы экономической социализации, экономическая культура, финансовая грамотность, финансовое образование.

\section{IMPLEMENTATION OF BASIC FORMS AND METHODS WHILE STUDYING "FINANCIAL LITERACY" COURSE IN GYMNASIUM}

\author{
Nataliia Baradiia \\ Candidate of Pedagogical Sciences \\ Research Fellow of the Department Studying Geography and Economy \\ Institute of Pedagogics of National Academy of Sciences of Ukraine \\ jolly2008@ukr.net
}

\begin{abstract}
The article represents a study of the importance of developing financial literacy among the modern youth. The author emphasizes on the fact that financial education helps students understand key financial concepts and use them to make financial decisions, choose appropriate financial instruments, budget planning, and raising funds for future goals, etc.

The features of effective teaching of "Financial Literacy" course in the gymnasium are revealed. Various approaches to the teaching process of this course are considered and the most effective ones are described. Taking into account the prospects for developing programs for the course "Financial Literacy" for the educational curriculum, the issue of training teachers of these categories for the introduction of financial education into institutions of general secondary education is relevant. It should be noted that certain aspects of the development of financial literacy of the population as one of the priorities of state policy at the present stage are considered by L. Zakharkina, L. Ziuman, T. Kizima, V. Kornivska, A. Kuznetsova, G. Kucherova, I. Lomachinska, D. Radzishevska, T. Smovzhenko and others.

Problems of introduction of financial education into educational institutions of Ukraine were studied by I. Vitenko, O. Gubenko, M. Koredenko, O. Kostiukova, T. Smovzhenko and others. The purposes of the article are to define the features of the implementation of basic forms and methods into the course "Financial Literacy" in the gymnasiums. The scientific novelty of the research results is the presence of original research material in the study. For the first time, features of effective teaching of "Financial Literacy" course in the gymnasium have been identified.

Thus, financial education is an effective factor in economic socialization, and this process is carried out by educators and teachers in their lifetime. Based on the results of the course "Financial Literacy", it is expedient to monitor the evaluation of the level of applicants' financial literacy and determine the current directions of further work on the implementation of financial education in gymnasium.
\end{abstract}

Key words: economic socialization; factors of economic socialization; economic culture; financial literacy; financial education. 


\section{Н. БАРАДІЯ}

Застосування основних форм і методів у вивченні курсу «Фінансова грамотність» у гімназії

\section{REFERENCES (TRANSLATED AND TRANSLITERATED)}

1.Bibik, N.M., Vashulenko, L.S. \& Lokshyna, O.I. (2004). Competency-based approach: reflexive application analysis. Competency approach in modern education. World experience and Ukrainian perspectives: b-ka of educational policy. O. V. Ovcharuk (Ed.), (pp. 47-52). Kyiv, Ukraine.

2. Kovtun, H.I. \& Martynenko, O.V. (2013) To the issue of the development of economic competence. Pedagogical sciences: theory, history, innovative technologies, 4, 135-144 s.

3. Lytvynova, S.H. (2011). The experience of Ukraine's teachers in using cloud services in the system of general secondary education. Kyiv, Ukraine: TOV TsP «KOMPRYNT».

4. Ovsiuk, N. (2011). Development of economic competence in the process of studying geography and the fundamentals of economics. Heohrafiia ta osnovy ekonomiky v shkoli, 1, 37-41.

5. Pometun, O.I. (2005). Competency-based approach - the most important benchmark for the development of modern education. Ridna shkola, 1, 65-69.

6. Khymynets, V. (n.d.). Competency-based approach to professional development of a teacher. zakinppo. org. ua. Retrieved from http:// zakinppo. org. ua / 2010-01-18-13-44-15 / 2332010-08-25-07-10-49/.

7. Chasnykova, O.V. (n.d.). Competency-based approach in education as the basis of its reform. narodnaosvita. kiev. ua. Retrieved from https: // www. narodnaosvita. kiev. ua / ?page_id=2607.

Матеріали надійшли до редакції 27.11.2018 р. 